\title{
Homologs of genes and anonymous loci on human Chromosome 13 map to mouse Chromosomes 8 and 14
}

\author{
T. Koizumi, ${ }^{1}$ E. Hendel, ${ }^{2}$ P.A. Lalley, ${ }^{3}$ M.-B.N. Tchetgen, ${ }^{2, *}$ J.H. Nadeau ${ }^{2, * * *}$ \\ ${ }^{1}$ Laboratory Animal Center, Fukui Medical School, Matsuoka, Fukui 910-11, Japan \\ ${ }^{2}$ The Jackson Laboratory, Bar Harbor, Maine 04609, USA \\ ${ }^{3}$ Center for Molecular Biology, Wayne State University, Detroit, Michigan 48202, USA \\ Received: 13 May 1994 / Accepted: 5 December 1994
}

\begin{abstract}
To enhance the comparative map for human Chromosome (Chr) 13, we identified clones for human genes and anonymous loci that cross-hybridized with their mouse homologs and then used linkage crosses for mapping. Of the clones for four genes and twelve anonymous loci tested, cross-hybridization was found for six, COL4A1, COL4A2, D13S26, D13S35, F10, and PCCA. Strong evidence for homology was found for COL4A1, COLAA2, D13S26, D13S35, and F10, but only circumstantial homology evidence was obtained for PCCA. To genetically map these mouse homologs (Cf10, Col4a1, Col4a2, D14H13S26, D8H13S35, and Pcca-rs), we used interspecific and intersubspecific mapping panels. D14H13S26 and Pcca-rs were located on the distal portion of mouse Chr 14 extending by $-30 \mathrm{cM}$ the conserved linkage between human Chr 13 and mouse Chr 14, assuming that Pcca-rs is the mouse homolog of PCCA. By contrast, Cf10, Col4a1, Col4a2, and D8H13S35 mapped near the centromere of mouse Chr 8, defining a new conserved linkage. Finally, we identified either a closely linked sequence related to Col4a2, or a recombination hot-spot between Col4a1 and Col4a2 that has been conserved in humans and mice.
\end{abstract}

\section{Introduction}

Comparative maps are an exceptional resource for identifying candidate genes and models for human genetic diseases and for studying genome organization and evolution (Copeland et al. 1993a). The comparative map for laboratory mice and humans currently consists of more than 1000 genes and conserved anonymous loci (Copeland et al. 1993b; Nadeau et al. 1995). An excellent example of the utility of these maps is the demonstration that the $P a x 3$ gene is mutated in mice with mutations at the Splotch locus (Epstein et al. 1991) and that the human homolog PAX3 is mutated in individuals with Waardenburg Syndrome Type I (Baldwin et al. 1992; Tassabehji et al. 1992). Comparative maps provided the crucial clue: among the many mouse mutations affecting neural crest derivatives in similar ways, only Splotch and Waardenburg Syndrome Type I map to homologous locations (Nadeau et al. 1991a). Recent examples of other uses of comparative maps for studying genome organization and evolution are the demonstration that human Chr 2 results from an ancient telomere-telomere fusion (IJdo et al. 1991) and that comparative physical maps generally verify

*Present address: Department of Urology, University of Michigan, Ann Arbor, Michigan 48109, USA.

**Present address: Department of Human Genetics and Department of Medicine, Montreal General Hospital, 1650 Cedar Avenue, Montreal, Quebec H3G 1A4, Canada.

Correspondence to: J. Nadeau in Montreal order and relative distances inferred from genetic maps (Kingsmore et al. 1989; Oakey et al. 1992).

Although progress in the development of the comparative map has been considerable with the number of markers in the map doubling the past 30 months, substantial portions of the genome remain poorly defined. An example is the suspected homology between the central-distal portion of human Chr 13 and the centraldistal portion of mouse Chr 14 (Nadeau et al. 1992; Copeland et al., 1993b). This suspicion is based on the presence of small clusters of homologous genes that flank both of these chromosome segments (Nadeau et al. 1995). To enhance the comparative map for human $\mathrm{Chr}$ 13, we identified and genetically mapped mouse homologs for four human genes and two anonymous DNA loci. Not only were we able to extend the conserved linkage involving human Chr 13 and mouse Chr 14, we identified a new conserved linkage involving human $\mathrm{Chr} 13$ and mouse $\mathrm{Chr} 8$, and found either a new pseudogene or a recombination hot-spot that has been conserved in the two species.

\section{Materials and methods}

Genes and anonymous loci. A description of the genes and anonymous loci selected for study is provided in Table 1 .

Genetic mapping panels. Two panels were used. The first was an intersubspecific mapping panel prepared by outcrossing (DS/Ei $\times$ MOLF/ Ei) $F_{1}$ females to $\mathrm{C} 3 \mathrm{H} / \mathrm{HeJ}$ males. DS/Ei is an inbred strain (F55) that is probably homozygous for the Disorganization mutation (Ds; Chr 14). MOLF/Ei is an inbred strain ( $\mathrm{F} 36+15)$ derived from $M$. musculus molossinus. The second panel was an interspecific panel prepared by backcrossing $(\mathrm{C} 57 \mathrm{BL} / 6 \mathrm{~J} \times M$. spretus $) \mathrm{F}_{1}$ females to $\mathrm{C} 57 \mathrm{BL} / 6 \mathrm{~J}$ males. Although the $M$. spretus strain was not fully inbred; residual variation is rare (J. Nadeau, unpublished; W. Dietrich and E. Lander, personal communication). This panel has been reported previously (see Nadeau et al. 1990, $1991 \mathrm{~b}$ and references therein).

Somatic cell hybrid analysis. A mouse-CHO somatic cell hybrid panel (Minna et al. 1975) was used to establish synteny. Occurrence of mouse chromosomes in this panel was previously reported (Popp et al. 1981).

Radiolabeling, Southern transfers, and hybridization. Methods described by Nadeau and Phillips (1987) were used.

Linkage analysis. A multilocus maximum likelihood program was used for calculating the LOD score for order (Nadeau et al. 1991b). This program is based on methods described by Bishop (1985).

\section{Results}

Identification of mouse homologs for COLAA1, COLAA2, D13S26, D13S35, F10, and PCCA through cross-hybridization and restric- 
Table 1. Description of clones used for identifying and typing mouse homologs of selected genes and anonymous loci from human Chr 13. Willianson et al. (1991) provide additional documentation of probe and clone characteristics. Bowcock and Taggart (1991), the NIH-CEPH Collaborative Mapping Group (1992), and the Cooperative Human Linkage Center (Buetow et al., 1994) provided documentation for current map localizations.

\begin{tabular}{|c|c|c|c|c|}
\hline $\begin{array}{l}\text { Gene or } \\
\text { anonymous locus }\end{array}$ & $\begin{array}{l}\text { Regional } \\
\text { localization }\end{array}$ & $\begin{array}{l}\text { Clone } \\
\text { name }\end{array}$ & Annotation & Reference \\
\hline COLAA1 & q34-qter & HT21 & $\begin{array}{l}\text { 2.7-kb cDNA corresponding to } 185 \text { amino acids of the carboxy-terminal Gly- } \\
\mathrm{X}-\mathrm{Y} \text { sequence, all of the carboxy-terminal domain, and the entire } 3 \text { ' untrans- } \\
\text { lated region of the alpha-1(IV) procollagen mRNA. }\end{array}$ & Bowcock ef al. 1988 \\
\hline COL $4 A 2$ & q34-qter & HT39 & $\begin{array}{l}\text { 1.7-kb cDNA corresponding to the carboxy-terminal domain and the entire } 3^{\prime} \\
\text { untranslated region of the alpha-2(IV) procollagen mRNA }\end{array}$ & Bowcock et al. 1988 \\
\hline D13S3 & q33-qter & p9A7 & anonymous genomic segment & Bowcock et al. 1991 \\
\hline D13S5 & $\mathrm{q} 31-\mathrm{q} 32$ & pHUB8 & anonymous genomic segment & Bowcock et al. 1991 \\
\hline D13S12 & $\mathrm{q} 21$ & pG18E2-1 & anonymous genomic segment & Bowcock et al. 1991 \\
\hline D13S24 & 一 & pG50 & anonymous genomic segment & Bowcock et al. 1991 \\
\hline D13\$26 & $\mathrm{q} 21$ & $\mathrm{pH} 2-10$ & anonymous genomic segment & Bowcock et al. 1991 \\
\hline D13S31 & $\mathrm{q} 14.3-\mathrm{q} 21.1$ & pCRI324 & anonymous genomic segment & Bowcock et al. 1991 \\
\hline D13\$32 & q34-qter & pCRI318 & anonymous genomic segment & Bowcock et al. 1991 \\
\hline D13\$35 & $\mathrm{q} 34$ & pCRI323 & anonymous genomic segment & Bowcock et al. 1991 \\
\hline D13\$39 & $\mathrm{q} 14.3-\mathrm{q} 22$ & WC25 & anonymous genomic segment & Bowcock et al. 1991 \\
\hline D13\$41 & $\mathrm{q} 14.3-\mathrm{q} 22$ & WC83 & anonymous genomic segment & Leppert et al. 1987 \\
\hline D13S55 & $\mathrm{q} 14.3$ & pCRI-R214 & anonymous genomic segment & Bowcock et al. 1991 \\
\hline F10 & q34-qter & peHX14 & $\begin{array}{l}\text { 1.44-kb cDNA corresponding to the leader peptide, the light and heavy chain } \\
\text { of the clotting factor, and the } 3^{\prime} \text { untranslated region }\end{array}$ & Fung et al. 1985 \\
\hline PCCA & $\mathrm{q} 32$ & pPCC9-5 & $\begin{array}{l}\text { 2-kb cDNA corresponding to a single open reading frame and including the } \\
\text { Ala-Met-Lys-Met codons that distinguish PCCA from PCCB. }\end{array}$ & Lamhonwah et al. 1986 \\
\hline
\end{tabular}

tion fragment analysis. To identify human clones that crosshybridize with corresponding sequences in the mouse genome, we selected four genes and twelve anonymous loci for study (Table 1). A clone for each locus was radiolabeled and hybridized to filters onto which endonuclease-digested, size-fractionated genomic DNAs from different strains of inbred mice had been transferred. Strong cross-hybridization was observed for COLAA1, COLAA2, D13S26, D13S35, F10, and PCCA (Fig. 1). For COL4A1, COL4A2, D13S26, D13S35, and F10, single restriction fragments were observed in strains that would subsequently be used for mapping (Table 2). Identification of these single restriction fragments provides strong evidence that the homologous mouse gene or anonymous locus has been identified. We propose the following symbols for the mouse homologs of these genes and anonymous loci: Cf10, Col4a1, Col4a2, D8H13S35, and D14H13S26. Only PCCA showed multiple fragments in all endonuclease-digested genomic DNAs tested (see Fig. 1F for example). It was, therefore, uncertain which PCCA-related fragment represented the homolo- gous mouse gene. Because of this ambiguity, we designate the mouse PCCA related sequence as Pcca-rs.

The weak cross-hybridization for D13S3, D13S5, D13S39, and D13S55 was unreliable for linkage analysis. Cross-hybridization was not detected for D13S12, D13S24, D13S31, D13S32, D13S34, or D13S41. Previous studies showed that $25 \%$ to $35 \%$ of anonymous human loci have a mouse homolog that can be detected through cross-hybridization (Cheng et al. 1988, 1989). We found reliable cross-hybridization for two of the twelve anonymous loci studied $(\sim 17 \%)$. This difference was not significantly different from the expected number (3 to 4 ) of reliably crosshybridizing clones.

D14H13S26 and Pcca-rs are located on Chr 14, but Cf10, Col4a1, Co14a2, and the mouse homolog of D13S35 are not. To test whether any of these six genes or anonymous loci are located on Chr 14, restriction fragment variants were identified (Fig. 1, Table

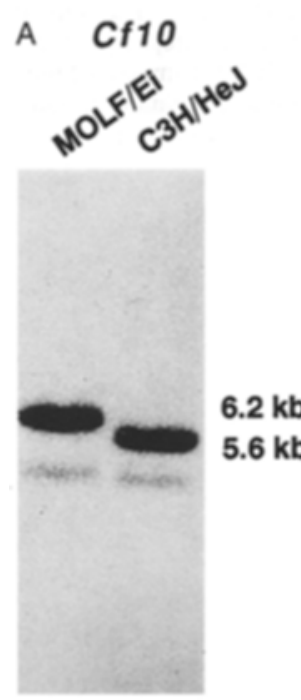

B Col4a1

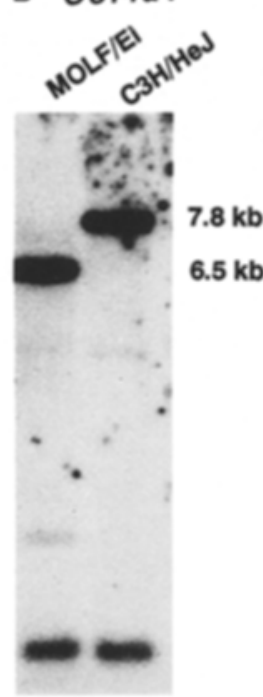

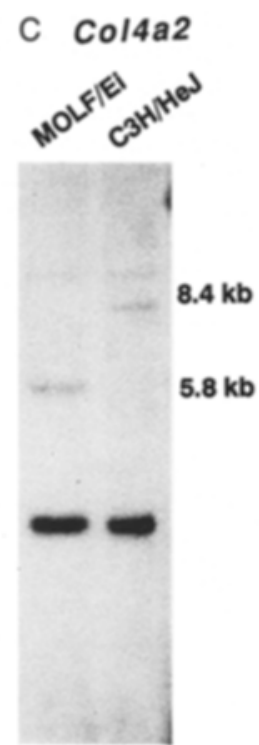

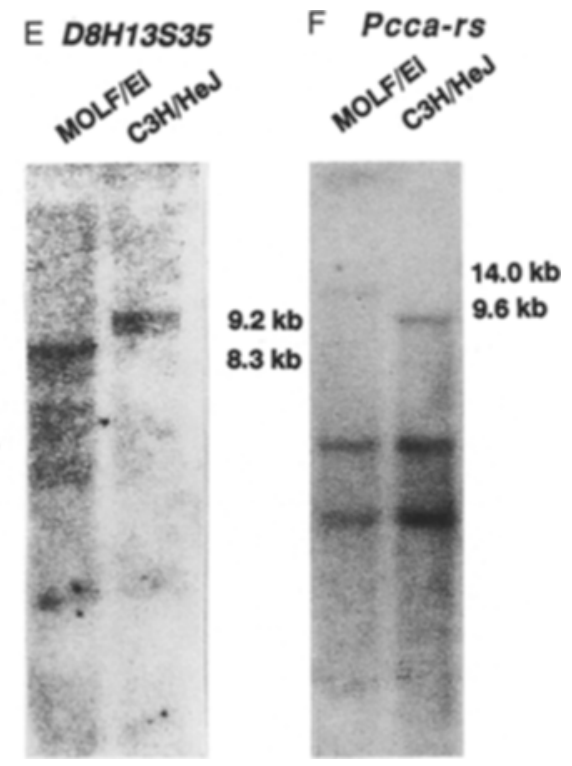

D D14H13S26

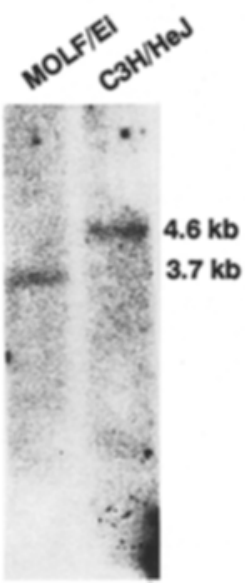

E D8H13S35
F Pcca-rs

$14.0 \mathrm{~kb}$
$9.6 \mathrm{~kb}$

Fig. 1. Representative cross-hybridization patterns of human clones with mouse genomic DNA. A. CfIO; B. Col4al; C. Col4a2; D. D14HI3S26; E. D8H13S35; and F. Pcca-rs. 
Table 2. Evidence for homology. Because a single restriction fragment was observed for the restriction enzyme indicated, there is strong evidence that the homologus mouse gene or locus was detected. The exception was PCCA (see text). Emphasis was placed on illustrating single fragments that were used for linkage analysis. 'rs' indicates 'relatedsequence'.

\begin{tabular}{|c|c|c|c|c|}
\hline $\begin{array}{l}\text { Human } \\
\text { locus }\end{array}$ & Strain & $\begin{array}{l}\text { Restriction } \\
\text { enzyme }\end{array}$ & $\begin{array}{l}\text { Fragment } \\
\text { size }(k b)\end{array}$ & $\begin{array}{l}\text { Proposed } \\
\text { mouse symbol }\end{array}$ \\
\hline $\overrightarrow{\mathrm{COL}} 4 \mathrm{AA} 1$ & $\mathrm{BALB} / \mathrm{cJ}$ & $E c o$ RI & 9.8 & Col4al \\
\hline COL $4 \mathrm{~A} 2$ & M. spretus & PstII & 4.0 & Col4a2 \\
\hline D13\$26 & MOLF/Ei & MspI & 3.7 & D14HI3\$26 \\
\hline D13\$35 & MOLF/Ei & $M s p \mathrm{I}$ & 8.3 & D8H13535 \\
\hline F10 & M. spretus & PstI & 3.7 & F10 \\
\hline PCCA & \multicolumn{3}{|c|}{$\begin{array}{l}\text { All enzymes tested produced multiple fragments in } \\
\text { each of the mouse strains and restriction enzymes } \\
\text { surveyed }\end{array}$} & Pcca-rs \\
\hline
\end{tabular}

3) and used for following inheritance in the (DS/EiNa $\times$ MOLF) $F_{1}$ $\times \mathrm{C} 3 \mathrm{H} / \mathrm{HeJ}$ intersubspecific mapping panel. This panel has been typed for more than $\sim 40$ genes and anonymous loci on Chr 14 (unpublished). Linkage was detected between $014 H 13 S 26, P c c a-$ $r s$, and several other loci including Es 10 and Tcra. Double crossovers were not detected. The LOD score for order was 4.0, providing strong support for the order illustrated in Fig. 2A. These loci extend the conserved linkage by $\sim 30 \mathrm{cM}$ to the distal portion of Chr 14, assuming that Pcca-rs is homologous to PCCA (Fig. 3). Unexpected results were obtained for Cf10, Col4a1, Col4a2, and the human homolog of D13\$35. Homologs for these loci were closely linked to each other, but were not linked to any other locus that has been mapped to Chr 14 (Figure 2B).

Synteny assignment with somatic cell hybrids: Cf10, Col4a1, $\mathrm{Col} 4 \mathrm{a} 2$ and the homolog of D13S35 are located on Chr 4 or Chr 8. To establish synteny, segregation of mouse-specific restriction fragment length variants for Cf10, Col4al, and Col4a2 (Table 3) was followed in a panel of 15 somatic cell hybrids. D13S35 was not studied because we assumed that if synteny was found for Cf10, Col4a1, and Col4a2, the chromosome assignment for the homolog of D13S35 would also be known because these four loci are closely linked. Complete cosegregation was observed between variants for these three loci and mouse Chrs 4 and 8 (results not shown). Ambiguity between these two chromosomes in this hybrid panel has a precedent that was resolved by using an interspecific backcross mapping panel (Nadeau et al. 1990).

Cf10, Col4a1, Col4a2 and D8H13S35 map to the centromeric region of $\mathrm{Chr} 8$. Restriction fragment length variants for $\mathrm{CflO}$ and Col4a2 (Table 3) were tested for linkage with loci that had been previously mapped to Chrs 4 or 8 in a $(\mathrm{C} 57 \mathrm{BL} / 6 \mathrm{~J} \times M$. spretus $) \mathrm{F}_{1}$ $\times$ C57BL/6J interspecific mapping panel (Nadeau et al. 1990).
These two genes showed linkage to genes on the centromeric region of Chr 8 (Fig. 2C). These results establish a new conserved linkage between mouse Chr 8 and human Chr 13 (Fig. 3).

An apparent difference in recombination frequency between the intersubspecific and interspecific crosses. Comparison of recombination frequencies revealed remarkable variation between the intersubspecific and interspecific crosses (Fig. $2 \mathrm{~B}$ and $2 \mathrm{C}$ ). In the intersubspecific cross, the corresponding recombination frequency was $17.3 \%$. In the interspecific cross by contrast, $C f l 0$ and $C o l 4 a 2$ failed to recombine $(\mathrm{N}=60)$; upper $95 \%$ confidence limit for the recombination frequency is 0.049 ). This difference in recombination frequency was highly significant (chi-square contingency test: $\left.\mathrm{X}^{2}=10.1, \mathrm{P}<0.001\right)$.

\section{Discussion}

The comparative map for human Chr 13. The comparative map for human $\mathrm{Chr} 13$ consisted of a $\sim 2 \mathrm{cM}$ conserved linkage composed of three genes (Es10, esterase-10; Htr2, seratonin receptor subtype-2; and $R b 1$, retinoblastoma-1) on mouse Chr 14, a shorter conserved linkage composed of two genes (Gja3, gap junction membrane channel protein alpha-2; Gjb2, gap junction membrane channel protein beta-2) on a separate portion of Chr 14, and a homology segment composed of a single gene (Flt3, FMS-like tyrosine kinase-3) on mouse Chr 5 (Nadeau et al. 1992, 1995; Copeland et al. 1993b). Together, these three segments in the mouse correspond to only a small portion of human Chr 13 (Fig. 3 ). The present study extended, perhaps by $\sim 30 \mathrm{cM}$, the conserved linkage on mouse Chr 14, assuming that Pcca-rs is the mouse PCCA gene (Fig. 3), and identified a new conserved linkage on mouse Chr 8 (Fig. 3). A substantial portion of human Chr 13 is now represented in the comparative map.

Table 3. Restriction fragment variants (RFLVs) used for mapping CflO, Col4al, Col4a2, D8H13S35, D14H13S26, and Pcca-rs. The following abbreviations were used to designate the restriction enzyme (RE) used for defining the RFLV: E, EcoRI; M, MspI; P, PstI; S, SstI; and X, XbaI. Fragment sizes are given in kilobases. If more than one fragment was detected for a particular locus, the fragment used for following segregation was underlined. The superscripts ' $\mathrm{s}$ ' (for strong) and 'w' (for weak) were used to denote a subjective assessment of the strength of cross-hybridization.

\begin{tabular}{|c|c|c|c|c|c|c|}
\hline Gene: & $C f 10$ & Col4al & Col4a2 & D3H13S35 & $D 14 H 13 S 26$ & Pcca-rs \\
\hline \multicolumn{7}{|c|}{ Intersubspecific mapping panel: } \\
\hline DS/Ei & $5.2^{\mathrm{w}}, 5.6^{\mathrm{s}}$ & $1.8^{\mathrm{w}}, 7.8^{\mathrm{s}}$ & $3.4^{\mathrm{s}}, 8.4^{\mathrm{w}}, 9.5^{\mathrm{w}}$ & 9.2 & 4.6 & $4.2^{\mathrm{s}}, 5.9^{\mathrm{s}}, 9.6^{\mathrm{w}}$ \\
\hline MOLF/Ei & $5.2^{\mathrm{w}}, \underline{6.2}^{\mathrm{s}}$ & $1.8^{\mathrm{w}}, 6.5^{\mathrm{s}}$ & $3.4^{\mathrm{s}}, 5.8^{\mathrm{w}}, 9.5^{\mathrm{w}}$ & 8.3 & 3.7 & $4.2^{\mathrm{s}}, 5.9^{\mathrm{s}}, 11.0^{\mathrm{w}}$ \\
\hline (Enzyme) & $(\mathrm{X})$ & $(\mathrm{X})$ & $(\mathrm{X})$ & $\overline{(\mathrm{P})}$ & $\overline{(\mathrm{M})}$ & (M) \\
\hline \multicolumn{7}{|c|}{ Somatic cell hybrids: } \\
\hline $\mathrm{BALB} / \mathrm{cJ}$ & 5.0 & 9.8 & $2.3,8.4$ & - & - & - \\
\hline $\mathrm{CHO}$ & $\overline{9.0}$ & $1.7,2.6$ & $\overline{9.8}$ & - & - & $\ldots$ \\
\hline (Enzyme) & (E) & (E) & (S) & & & \\
\hline \multicolumn{7}{|c|}{ Interspecific mapping panet: } \\
\hline $\mathrm{C} 57 \mathrm{BL} / 6 \mathrm{~J}$ & 3.4 & 一 & 2.5 & - & - & $\longrightarrow$ \\
\hline M. spretus & 3.7 & - & 4.0 & - & - & $\longrightarrow$ \\
\hline (Enzyme) & $\overline{(\mathrm{P})}$ & & $(\bar{P})$ & & & \\
\hline
\end{tabular}


A

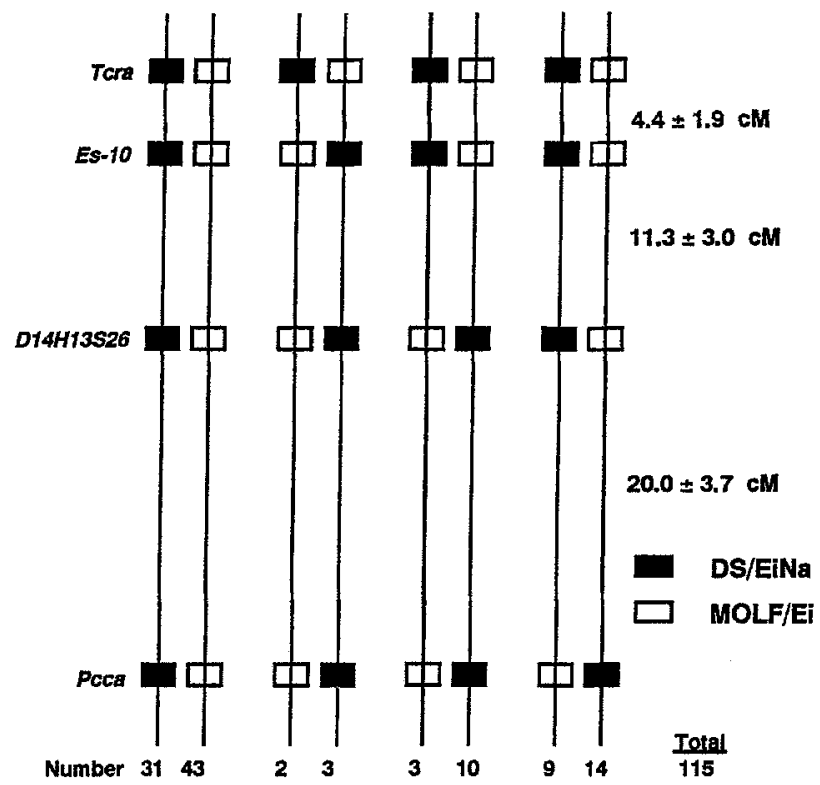

Fig. 2. Segregation data and linkage analysis for loci mapped to $\mathrm{Chr} 8$ or Chr 14. A. Chr $14-(\mathrm{DS} / \mathrm{Ei} \times \mathrm{MOLF} / \mathrm{Ei}) \mathrm{F}_{1} \times \mathrm{C} 3 \mathrm{H} / \mathrm{HeJ}$; B. Chr $8-$ $(\mathrm{DS} / \mathrm{Ei} \times \mathrm{MOLF} / \mathrm{Ei}) \mathrm{F}_{1} \times \mathrm{C} 3 \mathrm{H} / \mathrm{HeJ}$; and $\mathrm{C} . \mathrm{Chr} 8-(\mathrm{C} 57 \mathrm{BL} / 6 \mathrm{~J} \times M$. spretus $) \mathrm{F}_{1} \times \mathrm{C} 57 \mathrm{BL} / 6 \mathrm{~J}$.

B

\section{Chromosome 8}

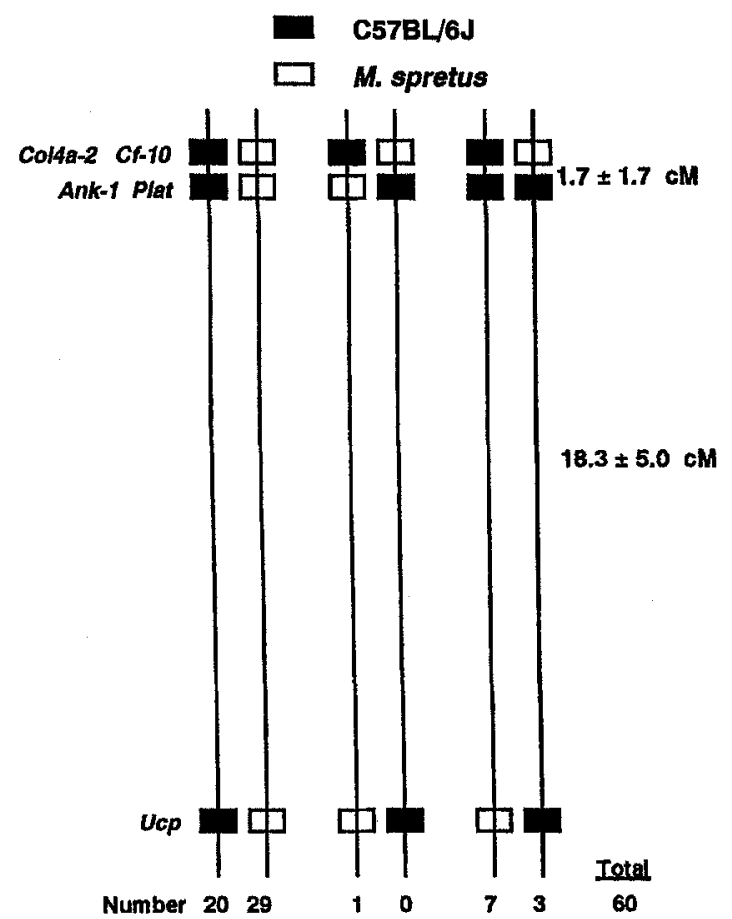

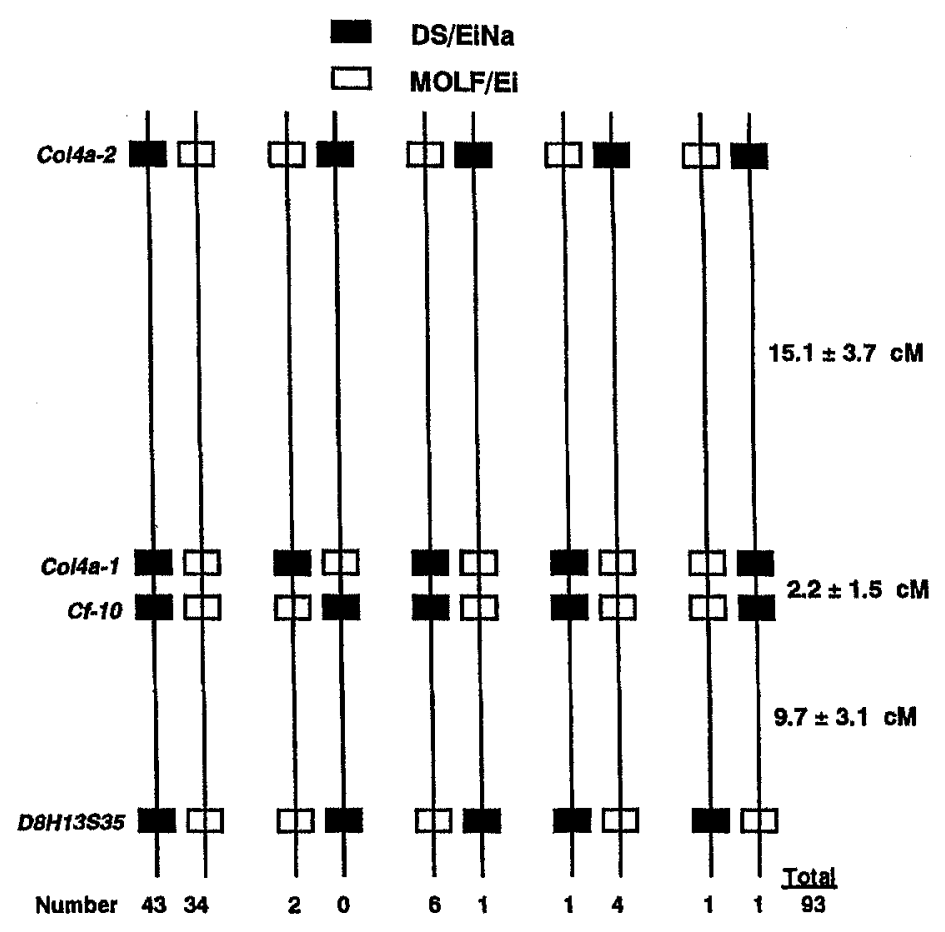

A COLAA1-COL4A2 recombination hot-spot in humans. The COL4A1-COL4A2 interval in humans has a strong recombination hot-spot. These two genes are less than $400 \mathrm{~kb}$ apart, they have a similar head-to-head arrangement, and their transcription start sites may be 42 bp apart (Cutting et al. 1988; Pöschl, et al. 1988; Soininen et al. 1988). Despite their close proximity, the recombination frequency of $2.8 \%$ is $\sim$ six-fold higher than expected (Bowcock et al. 1988). This is a minimum estimate of hot-spot activity because, if the genes were closer, the magnitude of recombination enhancement would be higher. More importantly, if some chromosomes have recombination hot-spots and others do not, that is, hot-spots are polymorphic in human populations, then pooled data would obscure heterogeneity and lead to underestimates of hotspot activity. In the CEPH families, two COL4A1-COL4A2 crossovers occurred in the same family (Bowcock et al. 1988), support- ing the argument that recombination frequency varies among chromosomes. Absence of detectable linkage disequilibrium is also consistent with a substantial recombination frequency (Bowcock et al. 1988). Mapping results for the mouse suggest a similar recombination hot-spot.

A Col4a2 pseudogene or a Col4a1-Col4a2 recombination hotspot. Among the 93 animals typed in the intersubspecific cross, fourteen crossovers were observed between sequences related to COL4A1 and COL4A2, yielding a recombination frequency of $15.1 \%$ (Fig. 2C). Physical mapping studies and DNA sequence analysis suggest that this recombination frequency is considerably higher than expected. In the mouse, these genes are arranged headto-head, transcription start sites are no more than $270 \mathrm{bp}$ apart, and 


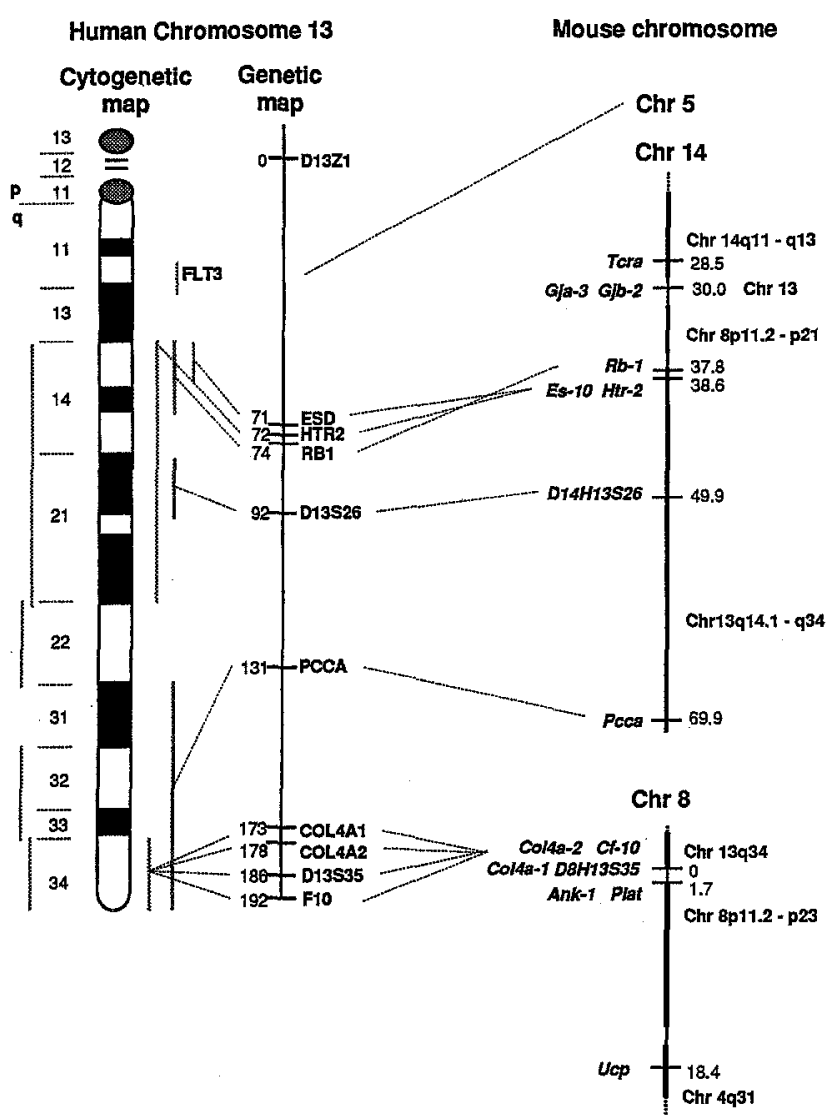

Fig. 3. Consensus comparative map for human $\mathrm{Chr} 13$ and corresponding segments of mouse Chrs 8 and 14. Conserved linkages are highlighted (Nadeau et al. 1992, 1995; Copeland et al. 1993b). Documentation for the human cytogenetic and genetic map localizations is provided by Bowcock and Taggart (1991), the NIH/CEPH Collaborative Mapping Group (1992), and Buetow et al. (1994). D13Z1 is a centromeric marker that was used to anchor the genetic map.

translation initiation codons are separated by 874 bp (Kaytes et al. 1988). A comparable physical arrangement of these genes is found in humans (Cutting et al. 1988; Pöschl et al. 1988; Soininen et al. 1988). If the ' 5 ' ends are approximately $270 \mathrm{bp}$ apart in the mouse as they are in humans (Cutting et al. 1988), then the expected recombination frequency is $-0.20 \% ; 1600 \mathrm{cM}$ in $3 \times 10^{9}$ bp corresponds to an average interval of $\sim 1900 \mathrm{~kb}$ between crossovers. The observed recombination frequency was $\sim 76$-fold higher than expected.

Two interpretations are possible for the unexpectedly high frequency of recombination between mouse homologs of COL4A1 and COLAA2. The first is that the COL4A2-related sequence that was mapped represents a sequence related to COL $A \mathrm{~A} 2$, possibly a pseudogene, but not Col4a2, itself. This related sequence is by chance linked to the Col4a2 gene. Inspection of representative restriction fragment patterns showed that the variant fragments that were used for mapping gave a weak hybridization signal; variants for the strongly hybridizing fragments were not detected (Fig. 1 and Table 3). Although single fragments were observed in C57BL/ $6 \mathrm{~J}$ and $M$. spretus, two fragments were observed in BALB/cJ, and multiple fragments were found in DS/Ei and MOLF/Ei. Several examples exist of sequences, probably processed pseudogenes, whose occurrence varies among inbred strains of laboratory mice and that are present in some strains and absent in others (Siracusa et al. 1991; Johnson et al. 1992, 1993, 1994; Richards-Smith and Elliott 1992). An alternative explanation is that, as in humans, a recombination hot-spot is located between mouse homologs of COL4A1 and COL4A2, as one is in human (Bowcock et al. 1988).
Alternative gene orders. Depending on the nature of the COLAA2related sequence that was mapped in the intersubspecific backcross, alternative gene orders are possible. If a COL4A2-related sequence was mapped, the most likely gene order would be Col4a1-D8H13S35-Cf10-Col4a2-rs. The Col4a1-D8H13S35Cf10 order is consistent with the order in humans (Bowcock et al. 1991; NIH/CEPH Collaborative Mapping Group 1992; Fig. 3). However, if the Col4a2 gene was mapped, an alternative order is more likely. Close physical proximity of Col4al and Col4a2 constrains interpretation of the recombination results because insufficient space $(<874 \mathrm{bp})$ is available to position $D 8 H 13 S 35$ and $C f 10$ between Col4al and Col4a2 (Cutting et al. 1988; Pöschl et al. 1988; Soininen et al. 1988). Given this constraint, the more likely order, illustrated in Fig. 3, is $\sim 10^{6}$ more likely than any other order.

Both of these orders suggest an exceptional pattern of crossingover. Considering the gene order illustrated in Fig. $2 \mathrm{C}$, nine of the fourteen mice with crossovers between Col4al and Col4a2 also had crossovers between Col4al and $C f 10$ or between $C f 10$ and D8H13S35. As a result, nine mice with double crossovers, but only seven mice with single crossovers, were observed. The double crossover frequency could be higher, because the five mice in which crossing-over was detected only between Col4al and Col4a2 could have a second crossover distal to $D 8 H 13 S 35$ or more probably proximal to Col4a2. The strong possibility therefore exists that crossing-over between $\mathrm{Col} 4 \mathrm{al}$ and $\mathrm{Col} 4 \mathrm{a} 2$ is always associated with crossing-over in a flanking interval. As a result, the only mice with single crossovers could be the two with crossovers between $C f 10$ and $D 8 H 13 S 35$. If the alternative order involving a Col4al pseudogene is correct, multiple crossovers are still involved. Other examples of clustered crossovers exist (Nadeau and Phillips 1987; Erhart et al. 1989; Nadeau et al. 1990). More detailed genetic and physical mapping studies involving specific combinations of chromosomes in laboratory mice should resolve this potentially interesting genetic problem.

Acknowledgments. We thank Dr. Anne Bowcock for sharing probes with us; Donna Burkart, Jeff Crosby, Terese Denial, Carolyn Dunbar, and Don Varnum for technical assistance; and Drs. Anne Bowcock and Toshihiko Shiroishi for reading a draft of the manuscript. E. Handel and M.-B.N. Tchetgen were supported by funds from the George I. Alden Trust, the Lucille P. Markey Charitable Trust, The Burroughs Wellcome Fund, the National Science Foundation, the Elizabeth S. Russell Scholarship Fund, and gifts in memory of Joseph P. Michelson. J.H. Nadeau was supported by grant HG00189 from the National Institutes of Health.

\section{References}

Baldwin, C.T., Hoth, C.F., Amos, J.A., da Silva, E.O., Milunsky, A. (1992). An exonic mutation in the HuP2 paired domain gene causes Waardenburg's syndrome. Nature 355, 637-638.

Bishop, D.T. (1985). The information content of phase-known matings for ordering genetic information. Genet. Epidemiol. 2, 349-361.

Bowcock, A., Taggart, R.T. (1991). Report of the committee on the genetic constitution of chromosome 13. Cytogenet. Cell Genet. 58, 580-604.

Bowcock, A.M., Hebert, J.M., Wijsman, E., Gadi, I., Cavalli-Sforza, L.L., Boyd, C.D. (1988). High recombination between two physically close human basement membrane collagen genes at the distal end of chromosome 13q. Proc. Natl. Acad. Sci. USA 85, 2701-2705.

Bowcock, A.M., Farrer, L.A., Hebert, J.M., Bale, A.E., Cavalli-Sforza, L.L. (1991). A contiguous linkage map of chromosome 13q with 39 distinct loci separated on average by 5.1 centimorgans. Genomics 11 , 517-529.

Buetow, K.H., Scherpbier-Heddema, T., Quillen, J., Murray, J.C., Sheffield, V.C., Duyk, G.M., Weber, J.L., Weissenbach, J., Gyapay, G., Dib, C., Vignal, A., Morrissette, J., Lathrop, G.M., White, R., Matsunami, N., Gerken, S., Melis, R., Albertsen, H., Ward, K., Plaetke, R., Odelberg, S., Ward, D., Bray-Ward, P., Menninger, J., Lieman, J., Desai, T., Banks, A. (1994). Human genetic map. Science 265, 2055-2070.

Cheng, S.V., Nadeau, J.H., Tanzi, R.E., Watkins, P.C., Jagadesh, J., Taylor, B.A., Sacchi, N., Gusella, J.F. (1988). Comparative mapping of DNA markers from the familial Alzheimer disease and Down syndrome 
regions of human chromosome 21 to mouse chromosomes 16 and 17. Proc. Natl. Acad. Sci. USA 85, 6032-6036.

Cheng, S.V., Martin, G.R., Nadeau, J.H., Haines, J.L., Bucan, M., Kozak, C.A., MacDonald, M.E., Lockyer, J.L., Ledley, F.D., Woo, S.L.C., Lehrach, H., Gilliam, T.C., Gusella, J.F. (1989). Synteny on mouse Chromosome 5 of human DNA loci linked to the Huntington's disease gene. Genomics 4, 419-426.

Copeland, N.G., Jenkins, N.A., Gilbert, D.J., Eppig, J.T., Maltais, L.J., Miller, J.C., Dietrich, W.F., Weaver, A., Lincoln, S.E., Steen, R.G., Stein, L.D., Nadeau, J.H., Lander, E.S. (1993a). A genetic linkage map of the mouse: current applications and future prospects. Science 262 , 57-66.

Copeland, N.G., Gilbert, D.J., Jenkins, N.A., Nadeau, J.H., Eppig, J.T., Maltais, L.J., Miller, J.C., Dietrich, W.F., Steen, R.G., Lincoln, S.E., Weaver, A., Joyce, D.C., Merchant, M., Wessel, M., Katz, H., Stein, L.D., Reeve, M.P., Daly, M.J., Dredge, R.D., Marquis, A., Goodman, N., Lander, E.S. (1993b). Genome maps IV: the mouse. Science 262, 67-82.

Cutting, G.R., Kazazian, H.H., Antonarakis, S.E., Killen, P.D., Yamada, Y., Francomano, C.A. (1988). Macrorestriction mapping of COL4A1 and COL4A2 collagen genes on human chromosome 13q34. Genomics $3,256-263$.

Epstein, D.J., Vekemans, M., Gross, P. (1991). Splotch ( $\mathrm{Sp} 2 H$ ), a mutation affecting development of the mouse neural tube, shows a deletion within the paired homeodomain of Pax-3. Cell 67, 767-774.

Erhart, M., Phillips, S.J., Bonhomme, F., Figueroa, F., Nadeau, J.H. (1989). Haplotypes mosaic for $t$-specific and wild-type variants in wild mice. Genetics 123, 405-415.

Fung, M.R., Hay, C.W., MacGillivray, R.T.A. (1985). Characterization of an almost full-length cDNA coding for human blood coagulation factor X. Proc. Natl. Acad. Sci. USA 82, 3591-3595.

Ijdo, J.W., Baldini, D., Ward, D.C., Reeders, S.T., Wells, R.A. (1991). Origin of human chromosome 2: an ancestral telomere-telomere fusion. Proc. Natl. Acad. Sci. USA 88, 9051-9055.

Johnson, K.R., Cook, S.A., Bustin, M., Davisson, M.T. (1992). Genetic mapping of the murine gene and 14 related sequences encoding chromosomal protein HMG-14. Mamm. Genome 3, 625-632.

Johnson, K.R., Cook. S.A., Ward-Bailey, P., Bustin, M., Davisson, M.T. (1993). Identification and genetic mapping of the murine gene and 20 related sequences encoding chromosomal protein HMG-17. Mamm. Genome 4, 83-89.

Johnson, K.R., Cook. S.A., Davisson, M.T. (1994). Identification and genetic mapping of 151 dispersed members of 16 ribosomal protein multigene families in the mouse. Mamm. Genome 5, 670-687.

Kaytes, P., Wood, L., Theriault, N., Kurkinen, M., Vogel, G. (1988). Head-to-head arrangement of murine type IV collagen genes. J Biol. Chem. 263, 19274-19277.

Kingsmore, S.F., Watson, M.L., Howard, T.A., Seldin, M.F. (1989). A $6000 \mathrm{~kb}$ segment of chromosome 1 is conserved in humans and mouse. EMBO J. 8, 4073-4080.

Lamhonwah, A.M., Barankiewicz, T.J., Willard, H.F., Muhuran, D.J., Quan, F., Gravel, R.A. (1986). Isolation of cDNA clones coding for the alpha and beta chains of human propionyl-CoA carboxylase: chromosome assignments and DNA polymorphisms associated with the PCCA and PCCB genes. Proc. Natl. Acad. Sci. USA 83, 48644868.

Leppert, M., Lathrop, M., O'Connell, P., Nakamura, Y., Cavenee, W.K., Cartwright, P., Lalouel, J.M., White, R. (1987). Extension of the primary genetic linkage map of chromosome 13. Cytogenet. Cell Genet. 46, 648.
Minna, J.D., Marshall, T.H., Shaffer-Berman, P.V. (1975). Chinese hamster $\mathrm{x}$ mouse hybrid cells segregating mouse chromosomes and isozymes. Somatic Cell Genet. 1, 355-369.

Nadeau, J.H., Phillips, S.J. (1987). The putative oncogene Pim-I in the mouse: its linkage and variation among $t$ haplotypes. Genetics, 533-541.

Nadeau, J.H., Birkenmeier, C.S., Crosby, J.L., Chowdhury, K., Lalley, P.A. (1990). Zinc finger protein gene complexes on Chromosomes 8 and 11. Genomics 8, 469-476.

Nadeau, J.H., Kosowsky, M., Steel, K.P. (1991a). Comparative gene mapping, genome duplication, and the genetics of hearing. Ann. N.Y. Acad. Sci. 630, 49-67.

Nadeau, J.H., Herrmann, B., Bucan, M., Burkart, D., Crosby, J.L., Erhart, M.A., Kosowosky, M., Kraus, J.P., Michiels, F., Schnattinger, A., Tchetgen, M.-B., Varnum, D., Willison, K., Lehrach, H., Barlow, D. (1991b). Genetic maps of mouse Chromosome 17 consisting of 12 new anonymous DNA loci and 25 anchor loci. Genomics 9, 78-89.

Nadeau, J.H., Davisson, M.T., Doolittle, D.P., Grant, P., Hillyard, A.L., Kosowsky, M., Roderick, T.H. (1992). Comparative map for mice and humans. Mamm. Genome 3, 480-536.

Nadeau, J.H., McCarthy, L., Cox, R. (1994). Mouse Chromosome 14. Mamm. Genome 5, S207-S216.

Nadeau, J.H., Grant, P.L., Mankala, S., Reiner, A.H., Richardson, J.E., Eppig, J.T. 1995. A Rosetta Stone for mammalian genetics. Nature 373, 363-365.

NIH/CEPH Collaborative Mapping Group (1992). A comprehensive genetic map of the human genome. Science 258, 67-86.

Oakey, R.J., Watson, M.L., Seldin, M.F. (1992). Construction of a physical map on mouse and human chromosome 1: comparison of $13 \mathrm{Mb}$ of mouse and $11 \mathrm{Mb}$ of human DNA. Hum. Mol. Genet. 1, 613-620.

Popp, R.A., Lalley, P.A., Whitney, J.B., Anderson, W.F. (1981). Mouse alpha-globin genes and alpha-globin-like pseudogenes are not syntenic. Proc. Natl. Acad. Sci. USA 78, 6362-6366.

Pöschel, E., Pollner, R., Kühn, K. (1988). The genes for the alpha 1 (IV) and alpha 2 (IV) chains of human basement membrane collagen type IV are arranged head-to-head and separated by a bidirectional promoter of unique structure. EMBO J. 7, 2687-2695.

Richards-Smith, B.A., Elliott, R.W. (1992). Mapping of the mouse ornithine decarboxylase-related sequence family. Mamm. Genome 2, 215232.

Siracusa, L.D., Jenkins, N.A., Copeland, N.G. (1991). Identification and applications of repetitive probes for gene mapping in the mouse. Genetics $127,169-179$.

Soininen, R., Huotori, M., Hostikka, S.L., Prockop, D.J., Tryggvason, K. (1988). The structural genes for alpha 1 and alpha 2 chains of human type IV collagen are divergently encoded on opposite DNA strands and have an overlapping promoter region. J. Biol. Chem. 263, 17217-17220.

Tassabehji, M., Read, A.P., Newton, V.E., Harris, R., Balling, R., Gruss, P., Strachan, T. (1992). Waardenburg's syndrome patients have mutations in the human homologue of the Pax-3 paired box gene. Nature 355 , 635-636.

Williamson, R., Bowcock, A., Kidd, K., Pearson, P., Schmidtke, J., Ceverha, P., Chipperfield, M., Cooper, D.N., Coutelle, C., Hewitt, J., Klinger, K., Langley, K., Beckman, J., Tolley, M., Maiduk, B. (1991). Report of the DNA committee and catalogues of cloned and mapped genes, markers formatted for PCR, and DNA polymorphisms. Cytogenet. Cell Genet. 58, 1190-1832. 